\title{
Comparative Study of Different Sewage Farming on Soil Quality
}

\author{
Avinash Dwivedi', Mr. Anupam Mehrotra², Mr. Kamal Nabh Tripathi ${ }^{3}$ \\ ${ }^{1}$ M.Tech Student, ${ }^{2}$ Associate Professor, ${ }^{3}$ Assistant Professor \\ 1,2,3Department of Civil Engineering, Babu Banarsi Das University, Lucknow, Uttar Pradesh, India
}

\begin{abstract}
How to cite this paper: Avinash Dwivedi | Mr. Anupam Mehrotra | Mr. Kamal Nabh Tripathi "Comparative Study of Different Sewage Farming on Soil Quality" Published in International Journal of Trend in Scientific Research and Development (ijtsrd), ISSN: 24566470, Volume-3 | Issue-4, June 2019, pp.124-127, URL: https://www.ijtsrd. com/papers/ijtsrd2 3701.pdf

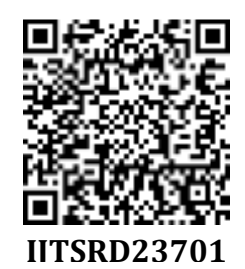

Copyright (C) 2019 by author(s) and International Journal of Trend in Scientific Research and Development Journal. This is an Open Access article distributed under the terms of the Creative Commons

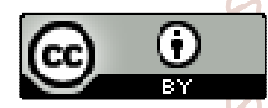
Attribution License (CC BY 4.0) (http://creativecommons.org/licenses/ by/4.0)
\end{abstract}

The Sludge is taken from centrifuge machine which removes the water content from sludge. The study shows by taking three plants namely Alovera, tomato and chilli and grown with sewage sludge, normal soil and chemical fertilizer. The normal soil taken is silty clay loam. The chemical fertilizer taken is Poorna 19 which contains nitrogen, present in ammonical, amide and nitrate forms, this further supplemented with zinc, iron, copper and manganese. The use of these chemical fertilizer always require a attention for proper dosage for better result. Firstly the physical test are performed and recorded which shows the sewage sludge is better compare to normal and chemical fertilizer. The rate of growth of plant with sewage sludge is much better than other two. Initially the research is performed in pot which doesn't show better effect initially. The water used for the irrigation is taken from the outlet of 6.5 MLD STP which further improves the soil quality as it also contains some parameter within the discharge limit to inland surface. The outlet water is taken before the chlorination stage. The reuse of treated water is common nowadays for small community in premises to make Zero Liquid Discharge scheme.

The sewage sludge in India is disposed far away from city which improves the soil quality of that area where it is disposed. The land where it is disposed is rich in nutrients after few years and the growth of vegetation is much better.
The research also focus on the application of sewage sludge spread on near by area in plant premises which result in green grass all over where the sewage sludge spreaded. Further the application of sewage sludge is done on various plants grown in premises. The results show the significant growth of tomato over all the field. The use of sewage is cost economical, eco-friendly and doesn't require enough attention for proper dosage. The sewage sludge as a fertilizer will solve the problem for disposal of sludge and providing almost zero costlier fertilizer to farmers.

\section{METHODOLOGY AND EXPERIMENTAL SETUP}

The comparative amount of nutrients in various soil are shown in the table 1

\begin{tabular}{|c|c|c|c|}
\hline & $\begin{array}{c}\text { Dry } \\
\text { Sludge }\end{array}$ & $\begin{array}{c}\text { Normal } \\
\text { Soil (\%) }\end{array}$ & $\begin{array}{c}\text { Chemical Fertilizer } \\
(\%)\end{array}$ \\
\hline $\mathrm{pH}$ & 8.3 & & 4 \\
\hline $\mathrm{NO}_{3}-\mathrm{N}$ & 38 & 0.9 & 4.50 \\
\hline $\mathrm{NH}_{4}-\mathrm{N}$ & 19.2 & 0.5 & 19 \\
\hline $\mathrm{PO}_{4}$ & 40.3 & 0.3 & 19 \\
\hline $\mathrm{K}$ & 4.2 & 2.8 & \\
\hline $\mathrm{SO}_{4}$ & 12.5 & 0.15 & 0.50 \\
\hline $\begin{array}{c}\text { Moisture } \\
\text { Content }\end{array}$ & 0.80 & 0.20 & \\
\hline
\end{tabular}

Table1. Amount of nutrient in Soil 
The water used for the irrigation of plants contain some amount of nutrient which is shown in table 2 which contain discharge parameter of STP

\begin{tabular}{|c|c|c|}
\hline Discharge Parameter & Inlet & Outlet \\
\hline Ph & 8.2 & 7.2 \\
\hline COD & 256 & 40 \\
\hline BOD & 190 & 12 \\
\hline TSS & 165 & 10 \\
\hline
\end{tabular}

Table2. Water quality of STP

Initially the dry sludge is mix with normal soil and group of three pot were prepared i.e one with normal soil, second with dry sludge mixture and third with chemical fertilizer.

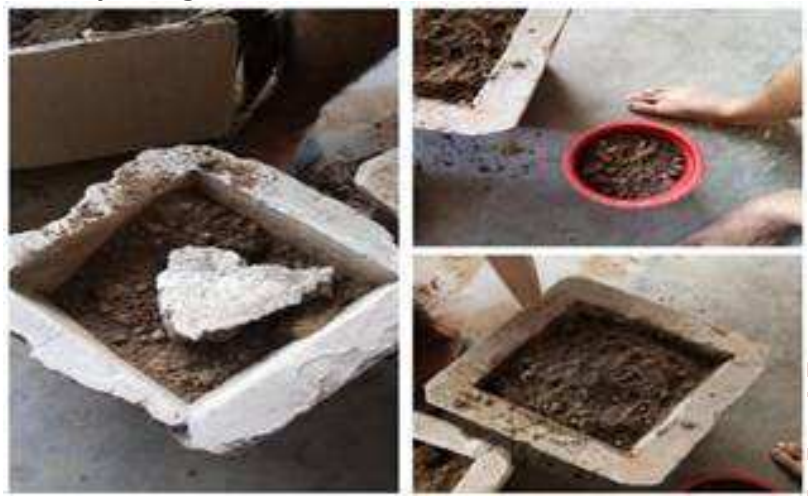

Fig1. First day of plantation

Results were recorded every fifteen day. The growth of plant were observed for every method of plantation.

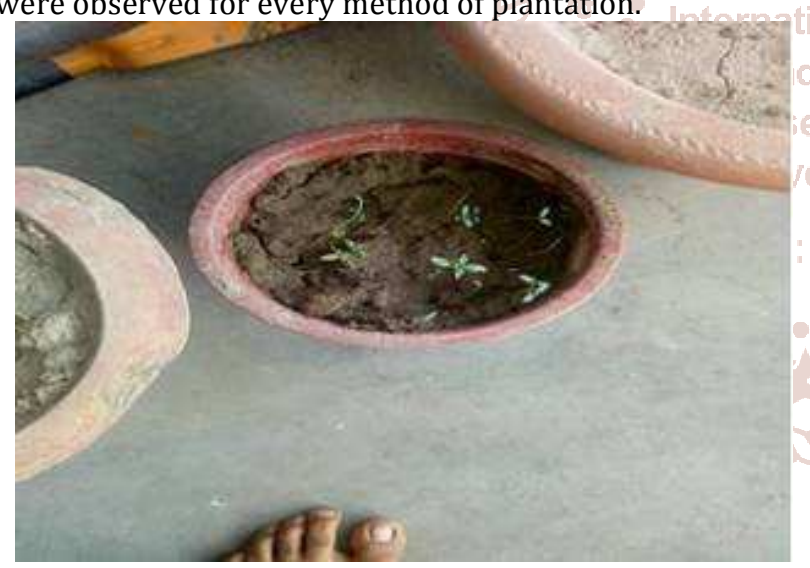

Fig2. Fifteenth day of plantation

After $15^{\text {th }}$ day the growth of seed is shown in fig2

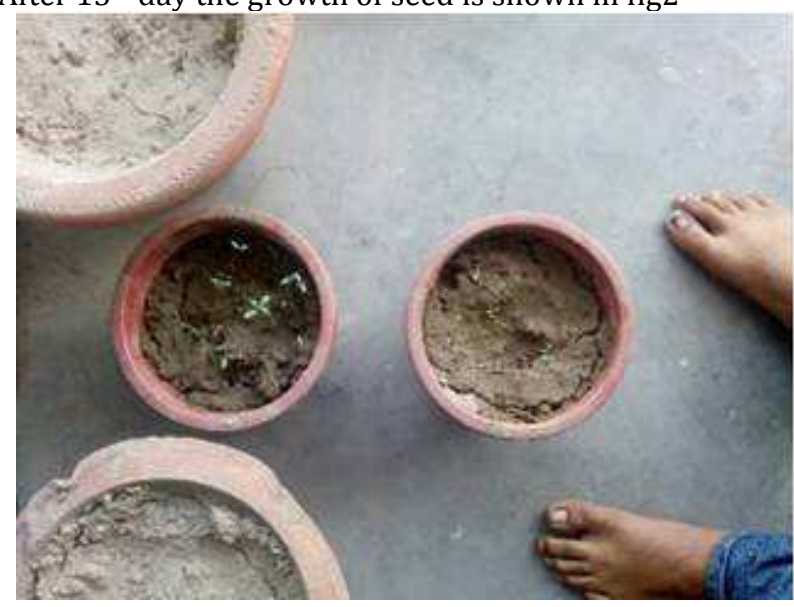

Fig3. Comparison of Sludge mixture soil with normal soil
In fig 3 the right side of pot contain normal soil plantation and left side pot contains sludge mixture soil.
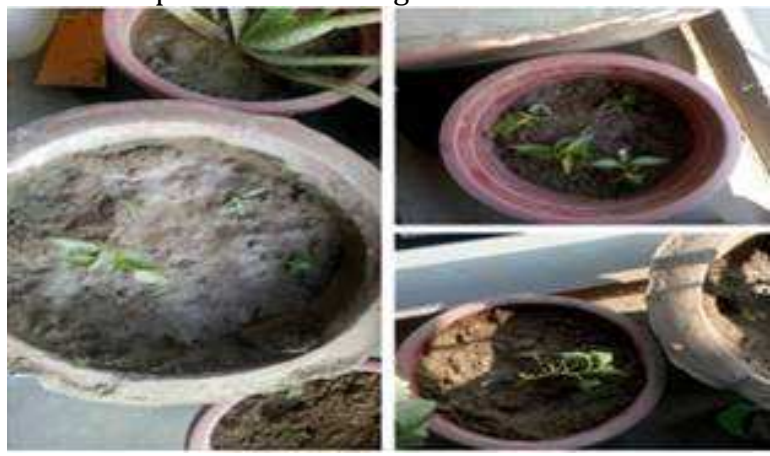

Fig 4. After 30 days of plantation of chi

\section{RESULTS}

After 60 day of plantation the growth of plant with sewage sludge is much better than other two. From the overall analysis that had been conducted, it was found that the plant being supplied by fertilizer had dead at early stage which is on $6^{\text {th }}$ week. This was the overload content of nutrients in the fertilizer. Theoretically, daily sludge application using the designed concentration will not cause any major problem to the plant but differ to the daily fertilizer application which caused harm and toxicity to the plant.

\begin{tabular}{|c|c|c|c|}
\hline & $\begin{array}{c}\text { Dry } \\
\text { Sludge }\end{array}$ & $\begin{array}{c}\text { Normal } \\
\text { Soil (\%) }\end{array}$ & $\begin{array}{c}\text { Chemical Fertilizer } \\
(\%)\end{array}$ \\
\hline $\mathrm{pH}$ & 8.3 & 7.5 & 6.8 \\
\hline $\mathrm{NO}_{3}-\mathrm{N}$ & 38 & 0.9 & 4 \\
\hline $\mathrm{NH}_{4}-\mathrm{N}$ & 19.2 & 0.5 & 4.50 \\
\hline Total $\mathrm{N}$ & 57.2 & 1.4 & 8.5 \\
\hline $\mathrm{PO}_{4}$ & 14.2 & 0.5 & 19 \\
\hline $\mathrm{N}: \mathrm{P}$ ratio & $4.02: 1$ & $2.8: 1$ & $0.44: 1$ \\
\hline $\mathrm{K}$ & 4.2 & 2.8 & 19 \\
\hline $\begin{array}{c}\mathrm{SO}_{4} \\
\text { Moisture } \\
\text { Content }\end{array}$ & 7.8 & 0.15 & \\
\hline $\mathrm{N}: \mathrm{S}$ ratio & $7.33: 1$ & 0.30 & 0.50 \\
\hline
\end{tabular}

Table3. Comparison of nutrients between sewage sludge and plants

\section{Content of nutrient in plants}

2 sets of data were obtained during the analysis as the plants that being fed with fertilizer were dead due to excess supply of nutrients. The nutrient content in plants receiving sewage sludge and treated water are shown in table 3 while ratio between nutrients cater by plants fed with sewage sludge and treated water of SBR plant are presented in table 3 above.

The optimum N:P ratio for most plants ranges from $5: 1$ to 10:1. According to table 3 the sewage sludge provides the dosage in the optimum range of plant.

\section{Growth Development of Alovera}

Initially the aloveera taken on the first day for plantation were $5.6 \mathrm{cms}, 4.8 \mathrm{cms}$ and $4.2 \mathrm{cms}$

\begin{tabular}{|l|l|l|}
\hline \multicolumn{1}{|c|}{ Aloovera height } & Initial (cms) & Final (cms) \\
\hline Sewage Sludge pot & 4.2 & 35 \\
\hline Normal soil pot & 5.6 & 24 \\
\hline Chemical fertilizer pot & 4.8 & 18 \\
\hline
\end{tabular}

Table4. Height of Alovera in different soil 


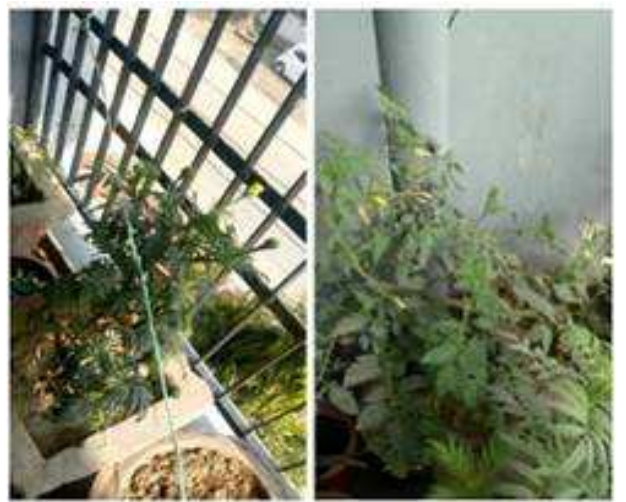

Fig5. final growth of plant

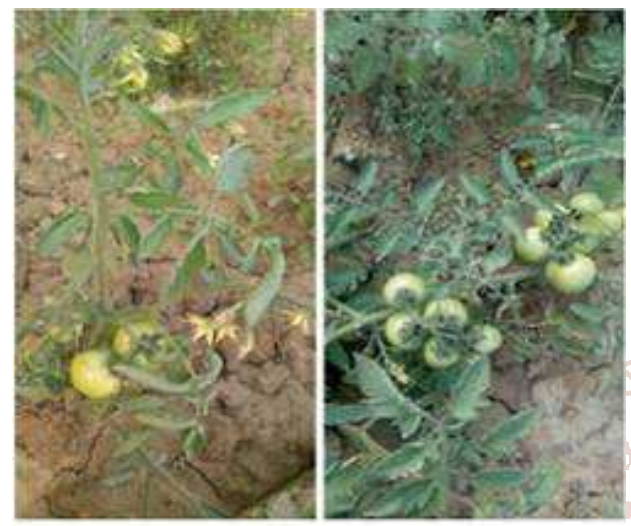

Fig6. Growth of tomato in 6.5 MLD premises

\section{CONCLUSION}

Sewage sludge potentially contains nutrients which can be used as fertilizers in order to enhance the plant growth

Major nutrients contain in sewage sludge is nitrogen, lopm phosphorous, potassium and sulfur and might contains some micro nutrients.

Though the utilization of sewage sludge will solve the problem for the disposal of STP sludge and it can be reused for developing green belts in the premises and nearby areas of STP.

\section{REFERENCES}

[1]. P. P. S. Gill, M. kumar, N. P. Singh and W. S. Dhillon, "Studies on macronutrient fertilization in pomegranate under sub-tropical plains" J. Hortl. Sci. Vol. 8(2):172175,2013

[2]. Silvana Apriliani, Sudradjat, Sudirman Yahya," Optimization of N, P and K Single fertilizer package for Oil palm aged four years" IJSBAR(2017) Volume 36 no. 1 pp 202-212

[3]. A. SUSS Beratungsbiiro fur Umweltfragen, USE OF SEWAGE SLUDGE AS A FERTILIZER FOR INCREASING SOIL FERTILITY AND CROP PRODUCTION XA9745794

[4]. Md. Lokman Hossain1, Mohammed Abdus Salam2, Ashik Rubaiyat3, Mohammed Kamal Hossain4 Sewage Sludge as Fertilizer on Seed Germination and Seedling Growth: Safe or Harm ISSN 2249-5908 Issue 3, Vol. 2 (March 2013)

[5]. Lucrezia Lamastra, Nicoleta Alina Suciu and Marco Trevisan Sewage sludge for sustainable agriculture:
$[12]$

contaminants' contents and potential use as fertilizer Lamastra et al. Chem. Biol. Technol. Agric. (2018) 5:10

[6]. Ma. del Mar DELGADO ARROYO, Miguel Ángel PORCEL COTS, Rosario MIRALLES DE IMPERIAL HORNEDO, Eulalia Ma. BELTRÁN RODRÍGUEZ, Luisa BERINGOLA BERINGOLA and José Valero MARTÍN SÁNCHEZ SEWAGE SLUDGE COMPOST FERTILIZER EFFECT ON MAIZE YIELD AND SOIL HEAVY METAL CONCENTRATION Rev. Int. Contam. Ambient. 18 (3) 147-150, 2002

[7]. Khalid Usman1, Sarfaraz Khan2, Said Ghulam3, Muhammad Umar Khan4, Niamatullah Khan1, Muhammad Anwar Khan1, Shad Khan Khalil5 "Sewage Sludge: An Important Biological Resource for Sustainable Agriculture and Its Environmental Implications" American Journal of Plant Sciences, 2012, $3,1708-1721$

[8]. European Commission, "Disposal and Recycling Routes of Sewage Sludge Part 3," Scientific and Technical Report, European Commission DG Environment, 2001

[9]. Department of Natural Resources and Environment, "Biosolids in Victoria-Report on Options for Benificial Use of Biosolids," 1998.

S. K. Dubey, R. K. Yadav, P. K. Chatuvedi, B. Goyel, R. Yadav and P. S. Minhas, "Agricultural Uses of Sewage Sludge and Water and Their Impact on Soil Water and Environmental Health in Haryana, India," Abstract of 18th World Congress of Soil Science, Philadelphia, 9-15 July 2006.

[11]. M. Q. Khan and J. I. Khan, "Impact of Sewage Waste (Effluent and Sludge) on Soil Properties and Quality of Vegetables," Final/Completion Report of ALP Project, Department of Soil Science, Faculty of Agriculture, Gomal University, Dera Ismail Khan, 2006.

B. J. Lindsay and T. J. Logan, "Field Response of Soil Physical Properties to Sewage Sludge," Journal of Environmental Quality, Vol. 27, No. 3, 1998, pp. 534-542.

[13]. N. V. Hue and S. A. Ranjith, "Sewage Sludge in Hawaii; Chemical Composition Reactions with Soils and Plants," Water, Air and Soil Pollution, Vol. 72, No. 1, 1994, pp. 265-283.

[14]. W. Rulkens, "Sewage Sludge as a Biomass Resource for the Production of Energy: Overview and Assessment of the Various Options," Energy \& Fuels, Vol. 22, No. 1, 2008, pp. 9-15.

[15]. M. J. Mohammad and B. M. Athamneh, "Changes in Soil Fertility and Plant Uptake of Nutrients and Heavy Metals in Response to Calcareous Soils," Journal of Agronomy, Vol. 3, No. 3, 2004, pp. 229-236.

[16]. C. Chatterjee and B. K. Dube, "Impact of Pollutant Elements on Vegetable Growing in Sewage Sludge Treated Soil," Journal of Plant Nutrition, Vol. 28, No. 10, 2005, pp. 1811-1820.

[17]. Joseph S. Mtshali1, Ababu T. Tiruneh1, Amos 0. Fadiran2 Characterization of Sewage Sludge Generated from Wastewater Treatment Plants in Swaziland in Relation to Agricultural Uses Resources and Environment 2014, 4(4): 190-199 DOI: $10.5923 /$ j.re.20140404.02 
[18]. Nyamangara, J. and Mzezewa, J. (2001). Effect of longterm application of sewage sludge to a grazed grass Zimbabwe. Nutrient Cycling in Agro ecosystems 59: 13-18

[19]. Terman, G. L., Soileau, J. M. and Allen, S.E. (1973). Municipal waste compost: Effects on crop yields and nutrient content in greenhouse pot experiments. Journal of Environmental Quality 2:84-89.

[20]. Stucky, D. J. and T. S. Newman, T.S. (1977). Effect of Dried an aerobically digested sewage sludge on yield and element accumulation in Tall Fescue and Alfalfa. Journal of Environmental Quality 6:271-74.

[21]. Smith, S. R. (1994). Effect of soil pH on availability to crops of metals in sewage sludge-treated soils. I. Nickel, copper and zinc uptake and toxicity to ryegrass. Environmental Pollution 85: 321-327.

[22]. Rocío VACA1, Jorge LUG01, Ricardo MARTÍNEZ1, María V. ESTELLER2 and Hilda ZAVALETA3 EFFECTS OF SEWAGE SLUDGE AND SEWAGE SLUDGE COMPOST AMENDMENT ON SOIL PROPERTIES AND Zea mays L. PLANTS (HEAVY METALS, QUALITY AND PRODUCTIVITY) Rev. Int. Contam. Ambie. 27(4) 303311,2011 pasture on organic carbon and nutrients of a clay soil in

[23]. Warman P. R. and Termeer W. C. (2005a). Evaluation of sewage sludge, septic waste and sludge compost applications to corn and forage: $\mathrm{Ca}, \mathrm{Mg}, \mathrm{S}, \mathrm{Fe}, \mathrm{Mn}, \mathrm{Cu}$, Zn and B content of crops and soils. Biores. Technol. 96, 1029-1038.

[24]. Warman P. R. and Termeer W.C. (2005b). Evaluation of sewage sludge, septic waste and sludge compost applications to corn and forage: yields, and N, P and $\mathrm{K}$ content of crops and soils. Biores. Technol. 96, 955961.

[25]. Singh R. P. and Agrawal M. (2007). Effects of sewage sludge amendment on heavy metal accumulation and consequent responses of Beta vulgaris plants. Chemosphere 67, 2229-2240.

[26]. Korboulewsky N., Dupouyet S. and Bonin G. (2002). Environmental risk of applying sewage sludge compost to vineyards: carbon, heavy metals, nitrogen, and phosphorus accumulation. J. Environ. Qual. 31, 15221527.

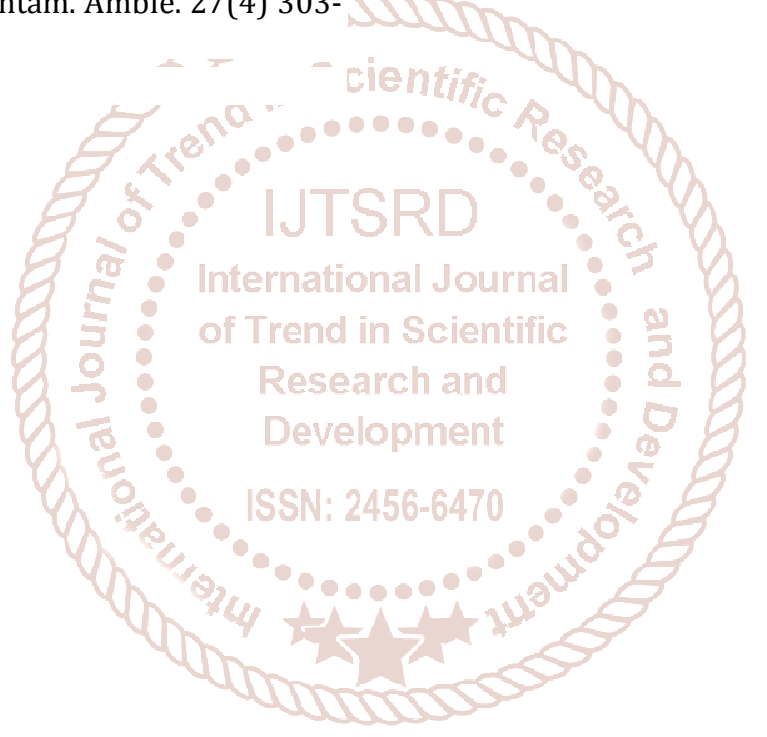

